\title{
Song for Teaching English Vocabularies in the Fourth Grade Students
}

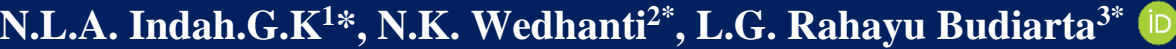 \\ 2,3 English Language Ganesha University of Education, Bali, Indonesia
}

\section{A R T I CL E I N F O}

Article history:

Received May 20, 2021

Revised May 22, 2021

Accepted July 22, 2021

Available online August 25, 2021

Kata Kunci:

Mengajar Bahasa Inggris, kosa kata, Lagu

Keywords:

Teaching English, vocabularies,

Songs

DOI:

http://dx.doi.org/10.23887/jpbi.v9i2. 35850

\section{A B S T R A C T}

\begin{abstract}
A B S T R A K
Ada beberapa masalah saat guru mengajar kosa kata. Banyak siswa yang kesulitan belajar Bahasa Inggris. beberapa faktor membuat beberapa kata sulit bagi siswa, seperti pengucapan, ejaan, panjang, dan kerumitan, arti, jangkauan. Hal ini berdampak pada kemampuan Bahasa ingris pada siswa yang rendah. Tujuan penelitian ini yaitu menganalisis aktivitas pengajaran kosakata bahasa Inggris pada siswa kelas empat. Jenis penelitian ini yaitu kualitatif dengan menggunakan metode deskriptif kualitatif. Subjek penelitian ini adalah guru dan 29 siswa kelas IV. Metode yang digunakan untuk mengumpulkan data yaitu observasi, wawancara, dan kuesioner. Instrument yang digunakan untuk mengumpulkan data yaitu lembar observasi dan kuesioner. Teknik yang digunakan untuk menganalisis data yaitu analisis deskriptif kualitatif dan kuantitatif. Hasil penelitian ini yaitu pengajaran kosakata yang digunakan oleh guru dalam penelitian ini yaitu lagu alfabet, benda, lagu hari, lagu bulan. Lagu yang paling sering digunakan adalah lagu alfabet. Guru menerapkan lagu alfabet pada awal atau akhir pelajaran. Lagu pengajaran yang paling menyenangkan adalah lagu Alphabet. Siswa sangat termotivasi dalam belajar bahasa Inggris ketika lagu ini diimplementasikan oleh guru. Oleh karena itu, peran guru sangat penting dalam memilih lagu-lagu yang dapat digunakan untuk mengajar mereka yang sesuai dengan kebutuhan dan kesukaan siswa.
\end{abstract}

There are some problems when the teacher teaches vocabulary. Many students have difficulty learning English. Several factors make some words difficult for students, such as pronunciation, spelling, length, complexity, meaning, range. This has an impact on the students' English ability, which is low. The purpose of this study is to analyze the activities of teaching English vocabulary to fourth-grade students. This type of research is qualitative using a qualitative descriptive method. The subjects of this study were teachers and 29 students of class IV. The methods used to collect data are observation, interviews, and questionnaires. The instruments used to collect data are observation sheets and questionnaires. The technique used to analyze the data is descriptive qualitative and quantitative analysis. The results of this study are the teaching of vocabulary used by the teacher in this study, namely alphabet songs, objects, songs of the day, songs of the month The most frequently used songs are alphabet songs. The teacher applies the alphabet song at the beginning or end of the lesson. The most enjoyable teaching song is the Alphabet song. Students are critical in learning English when the teacher implements this song. Therefore, the teacher's role is critical in choosing songs that can be used to teach them according to students' needs and preferences.

This is an open access article under the CC BY-SA license. Copyright @ 2021 by Author. Published by Universitas Pendidikan Ganesha.

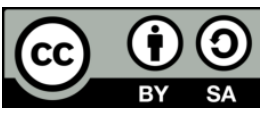

\section{INTRODUCTION}

Teaching English to a young learner is important for the learner to earlier and greater get chances for English proficiency (Khalil, 2018; Lou et al., 2013). The learner has an opportunity to have good pronunciation, improving overall performance, and have superior problem solving such as developing the ability to communicate with many people (Dashtestani, 2013; Gharti, 2019). Teaching for young learners will achieve the goal of the teacher can provide them with a pleasant learning situation (Alvi \& Ahmed, 2011; Chotitham \& Wongwanich, 2014). it can reduce young learners' hate for learning languages. Generally, in teaching English to the young learner, a teacher will be focused on many aspects of English and also skills, four aspects should be used by the teacher such as spelling, pronunciation, vocabulary, and grammar (Asghar et al., 2018; Risnawati \& Nuraeni, 2019). Besides that for the four skills called speaking, listening, writing, and reading. Those four aspects can develop four skills in English (Albashtawi \& Al Bataineh, 2020; Khalil, 2018). One of the important aspects to learn is vocabulary. Presently, learning vocabulary is important to help students understand English easier. It is a basic element of language (Destiyanti et al., 2021; Parvareshbar \& Ghoorchaei, 2016).

In the English teaching process, there are some problems while teachers teach vocabulary. Many students have difficulty learning English (Risnawati \& Nuraeni, 2019; Suwana et al., 2013). Students find it challenging to memorize English vocabulary (Habibi, 2017). Based on the results of previous studies, it was stated that children 
had difficulties in learning English because the teacher did not choose the appropriate learning method for students (Alavi \& Akbarian, 2020; Destiyanti et al., 2021). Other research also states that the lack of learning media that can make it easier for students to learn is also a significant factor (Anindyajati \& Choiri, 2017; Parvareshbar \& Ghoorchaei, 2016). In addition, several factors make some words difficult for students, such as Pronunciation, Spelling, Length, and complexity, Meaning, Reach (Kusumawati et al., 2017; Talebi \& Marzban, 2015). If students have difficulty memorizing English vocabulary, it will impact students' low English skills. This problem is also found in elementary schools. Based on the results of observations and interviews conducted at SD N 1 Kalibukbuk, it was found that the problem was the low ability of the students to speak English. This is because students are less able to remember English vocabulary. Students have difficulty remembering vocabulary. In addition, teachers also use learning methods that are not appropriate in the learning process so that students have difficulty in learning. This causes students difficulty in learning. There are some problems faced by the teacher in handling the class during this pandemic such as some of the students do not have the facility of online class, and some students' parents do not understand how to use or apply tools in having online classes, etc.

In teaching vocabulary teachers to have many roles or strategies to deliver the vocabulary for their students (Anindyajati \& Choiri, 2017; Kusumawati et al., 2017). One of the best strategies by the teacher is called song (Hasiana \& Wirastania, 2018; Roffiq et al., 2017). There are many kinds of songs that may use in the learning process. And it can make most people especially learners will help them very easily in the process of working on various elements of language learning (Aguirre et al., 2016). Learning of foreign language, music, or song can establish a beautiful learning atmosphere and it can entertain the learners (Albaladejo et al., 2018; Lawson-Adams et al., 2022). Songs and music lower restlessness if they are introduced in the early years of language learning, songs and music incline to create enjoyable, anxiety-free environment, songs help teach vocabulary, songs cater as a great listening material, songs also used as supplemental texts at the end of the lesson, on unique occasions or as an extra component for vocabulary development, songs and music can be used to motivate grammar presentation, practice, and revision, and songs and music bring sundry cultures into the classroom (Hua \& Wang, 2021; Leona et al., 2021). Besides, music is a thing that is indeed very universal and needed in the world, every culture or place has music.

The findings of previous studies also stated that the learning method using music would increase students' enthusiasm for learning (Lestari et al., 2017; Prahesti et al., 2020). Other research findings also state that songs will make it easier for students to learn (Prananda et al., 2020; Rani et al., 2019). There is no study on the use of English Vocabulary Teaching songs for Class IV Students. The purpose of this study is to analyze the use of English Vocabulary Teaching songs for Fourth Grade Students. The use of English Vocabulary Teaching songs is expected to improve students' vocabulary skills.

\section{METHOD}

The research used in this research is descriptive with a qualitative approach. Descriptive qualitative research involves the description, interpretation of situations, and conditions used to explain in research reports (Hancock, 2006). In this study, qualitative research was used to explore teaching English vocabulary to fourth graders and to clarify the use of songs in teaching vocabulary to fourth graders. The location of this research is SD N 1 Kalibukbuk which is located at Jl. Raya Kalibukbuk-Banyualit, Lovina Singaraja. The novelty in this research is the setting, no previous researcher has researched SD N 1 Kalibukbuk, and there is also one English teacher who usually handles several classes or classes. The methods used in collecting data are observation, interviews, and questionnaires. In collecting data, researchers used two instruments, namely, observation sheets and interview guidelines. Researchers used observation sheets to get data about teacher activities teaching English vocabulary to fourth-grade SD N 1 Kalibukbuk. The interview guide collected information about the reasons for using songs, advantages, and difficulties encountered when using songs for teaching English vocabulary. The technique used in analyzing the data is descriptive qualitative and quantitative analysis.

\section{RESULT AND DISCUSSION}

\section{Result}

The first teaching activity done by the teacher in teaching English vocabulary of students in SD N 1 Kalibukbuk was giving English songs as pre-activity in purpose to brainstorm students before they starting the teaching and learning activity. The teacher said that song was used to brainstorm and check the students' understanding. The purpose of brainstorming is to guide people to new ways of thinking and take a break from the common way of reasoning. Brainstorming is the automatic act of note-taking of ideas in preparation for different steps of language skill learning. Starting a lesson with brainstorming can increase learners' motivation. 
Brainstorming is a valuable technique in developing students' ideas before they start their language task. Thus, brainstorming through using songs is seen as an effective and engaging way to start the lesson. Then, during the main activity, the teacher introduced vocabulary to the students by giving students' some questions and material related to the songs. Before ending the lesson, the teacher used a quiz to check students' understanding of the material. The teacher asked students to prepare for the next lesson in the next meeting.

The next activity used was Q\&A to brainstorm the students, as usual, the questions used were related to the song that was given at the last meeting. Then, in the main activity teacher used the English song again in focusing their knowledge about learning vocabulary. After that, he gave students questions related to the song and asked them to answer the question correctly. At the end of the lesson, a teacher gave students a quiz related to the song. The third activity used by the teacher was a quiz, it was related to the songs before. Then for the main activity, the teacher gave students new English songs then asked them to be able to answer the question that had been prepared by the teacher. During the post-activity, a teacher asked students to divine themselves become some group, then he gave students a quiz again which was related to songs.

The next activity given by the teacher was Q\&A, which was related to the last material that was given by the teacher in the last meeting. During the main activity teacher gave students songs and divine them becomes groups by their numbers, they got questions and they had to answer the question. Then at the end of the lesson, a teacher gave the song again and gave students some homework. The fifth activity used by the teacher was a quiz. It was related to the last material. Then the teacher gave a song for the students. During the main activity, a teacher gave students questions such as a blank question. In the post-activity by the teacher, he asked students to answer the questions. The next activity was Q\&A, which was related to songs. Then the teacher invited students to answer some questions and gave them a new song. And the last activity by a teacher has used the quiz, it was related to the main activity before. Thus, the activities done by the teacher in teaching English vocabulary at SD N 1 Kalibubuk were used English songs.

From the result of 10 times observations, the teacher used several songs in teaching English vocabulary. The first song was Alphabet songs. There were several procedures or steps used by the teacher to teach English using the songs at the first meeting. At the preparation stage, the activities carried out are: The teacher prepares the link of the Alphabet Song, which is it was download from youtube and The teacher told the title of the song. The teacher sent the link by the WhatsApp application, the students were given time to watch and listen to that song. After that, he asked students to give their comments about the video. The teacher sent about some questions such as "giving a test about spelling name of family and oneself". The students should answer the question that was written on the Whatsapp group application. If the students could not answer the question, they were given a punishment such as a sing Alphabet song and send it to WhatsApp groups or other agreed punishment. From the result of the interview, the teacher said that the songs were used to attract students' attention in learning English. Besides, the Alphabet song was very enjoyable for the students so they were motivated to learn.

The next songs used were Days in English and the alphabet song. In this way, the students were asked to listen and watch the song. In the process of implementation that is the teacher asked students about the last material which focused on the songs, and The teachers selected the English song and share the link. The teacher gave the questions to the students which related to the last material he gave, it was a quiz to brainstorm. After that, a teacher gave students a link to a song, he sent it to the WhatsApps group, the song's title was "Days in English". The teacher asked the students to listen and watch it. Besides, the teacher gave student question such as blank questions which related to the song. The question such a people's stories of their daily routine in a week. After that, students must answer and share their answers with the group. After they share their answer, a teacher gave students a quiz related to the songs. From the interview, the teacher said that the song with the title "Days in English" was very good for the students to practice their English and, especially English vocabulary. Even the student's study by an online situation, at least they were studying and can discuss with their friends. This kind of activity should be done frequently to improve students' speaking and develop their vocabulary. The next songs used were Alphabet songs and Name of months in English. Those songs were used to practice vocabulary, and develop it. The implementation of those can be seen in Table 1.

Table 1. The Implementation of song

\section{Preparation}

Implementation

1. The teacher prepares the link of the alphabet song and months, which were download from youtube too.

2. The teacher told the title of the songs were Alphabet and Names of months

The teacher sent the link by the WhatsApp application, the students were given time to watch and listen to that song. After that, the teacher sent about some questions such as " giving a test about spelling name of family and oneself and name of months". The students should answer the question 

and the teacher asked students to be grouped. If the students could not answer the question, they were given a punishment such as a sing Alphabet song and send it to WhatsApp groups or other agreed punishment.

\section{Discussion}

Effective learning supports students to learn quickly, is fun, and can achieve the learning objectives that have been set (Aziz et al., 2020; Utomo et al., 2020; Zarei \& Afshar, 2014). The learning process is defined as a teacher teaching material to students while students listen to explanations from the teacher, but a teacher must create a lively teaching and learning atmosphere (Nisa et al., 2015; Nur Utami \& Mustadi, 2017). Students must participate in learning activities so that the learning situation becomes fun (Asthira et al., 2016; Chilmi et al., 2020). To create a pleasant English classroom atmosphere, one of them is songs for learning media (Aguirre et al., 2016; Albaladejo et al., 2018). To teach English to elementary school (MI) children, an English teacher chose the right song. The songs used in this study are alphabet songs, day songs, month songs, etc. the teacher chooses a simple song by learning needs. Choose a song with lyrics that can be heard clearly and correct pronunciation and is easily accessible to students (Capraro et al., 2012; Lawson-Adams et al., 2022).

The teacher said that using those songs was effective. It can make students more interested to learn (Eugenia et al., 2013; Ifadah \& Aimah, 2018). Those also able to introduce new vocabulary to the students in an engaging way. Based on the result of the interview, the teacher said the most enjoyable songs for students were the Alphabet song, However; it sometimes creates chaos in a classroom when the students lost their focus on learning. The other songs used were seen to be effective by the teacher depends on the learning material and the teacher's ability in using them. It was also observed that the students had a good response to the teacher's ways of teaching vocabulary. They could enjoy the process in teaching and learning process. These songs are the most enjoyable ways for the students (Gozcu \& Caganaga, 2016; Ratminingsih, 2018). The use of songs offers an opportunity to use the target language and build collaboration among students (Ait-Hajji and Kim, 2019).

\section{CONCLUSION}

The teaching vocabulary by using songs used by the teacher in this study was a lot of songs, such as alphabet songs, things, days songs, month songs, etc. The most frequent songs used were alphabet songs. The teacher implemented an alphabet song at the beginning of the end of the lesson. The teacher said that the alphabet song was used to brainstorm and check the students' understanding. From the teaching English by the use of songs by a teacher in teaching English for the students in this school, the most enjoyable teaching songs were Alphabet songs. Students were very motivated in learning English when this song was implemented by the teacher. Thus, the role of a teacher is essential in selecting the songs that may be used to teach them that based on the students' needs and loved.

\section{REFERENCES}

Aguirre, D., Bustinza, D., \& Garvich, M. (2016). Influence of Songs in Primary School Students' Motivation for Learning English in Lima, Peru. English Language Teaching, 9(2), 178. https://doi.org/10.5539/elt.v9n2p178

Ait Hajji, K., \& Kim, Y. (2019). Teaching and Learning Grammar by Games In EFL Classrooms in Moroccan High Schools. International Journal of English and Education, 3(2), 581-584. https://www.semanticscholar.org/paper/Teaching-and-Learning-Grammar-by-Games-In-EFL-ClassKim/b5b275cd0adb582908e7fd40911511531fd293b3

Alavi, S. M., \& Akbarian, I. (2020). The role of vocabulary size in predicting performance on TOEFL reading item types. System, 40(3). https://doi.org/10.1016/j.system.2012.07.002

Albaladejo, S. A., Coyle, Y., \& Larios, J. R. de. (2018). Songs, stories, and vocabulary acquisition in preschool learners of English as a foreign language. System, 76. https://doi.org/10.1016/j.system.2018.05.002

Albashtawi, A. H., \& Al Bataineh, K. B. (2020). The effectiveness of google classroom among EFL students in Jordan: An innovative teaching and learning online platform. International Journal of Emerging Technologies in Learning, 15(11), 78-88. https://doi.org/10.3991/IJET.V15I11.12865 
Alvi, F., \& Ahmed, M. (2011). Complexity analysis and playing strategies for Ludo and its variant race games. IEEE Conference on Computational Intelligence and Games, October 2011, 134-141. https://doi.org/10.1109/CIG.2011.6031999

Anindyajati, Y. R., \& Choiri, A. S. (2017). The effectiveness of using Wordwall Media to increase science-based vocabulary of students with hearing impairment. European Journal of Special Education Research, 2(2), 113. https://doi.org/10.5281/zenodo.236877

Asghar, A., Jamil, I., Iqbal, A., \& Yasmin, M. (2018). Learner Attitude towards EFL Learning: A Response from Art and Design. Journal of Social Sciences, 06(05), 81-88. https://doi.org/10.4236/jss.2018.65007

Asthira, Kusmariyatni, \& Margunayasa. (2016). Pengaruh Model Pembelajaran Learning Cycle "5e" Terhadap Hasil Belajar IPA Siswa Kelas V Di Gugus III. Mimbar PGSD Undiksha, 4(1). https://doi.org/10.23887/jjpgsd.v4i1.6658

Aziz, A. F., Kusumaningsih, W., \& Rahmawati, N. D. (2020). Pengaruh Model Pembelajaran Missouri Mathematics Project (MMP) dengan Strategi Think Talk Write (TTW) Terhadap Kemampuan Pemecahan Masalah Matematika Siswa SMP. Imajiner: Jurnal Matematika Dan Pendidikan Matematika. https://doi.org/10.26877/imajiner.v2i2.5774

Capraro, M. M., Song, Tingting, Rangel-Chavez, A. F., \& Harbaugh, A. (2012). An investigation of preservice teachers' use of guess and check in solving a semi open-ended mathematics problem. The Journal of Mathematical Behavior, 31(1). https://doi.org/10.1016/j.jmathb.2011.10.002

Chilmi, F. I., Sina, I., \& Utami, W. B. (2020). The Effectiveness of Course Review Horay Learning Model with Adobe Flash Assistance to See Interests Aad Abilities. Mathematics Education Journal, 3(2). https://doi.org/10.22219/mej.v3i2.11050

Chotitham, S., \& Wongwanich, S. (2014). The Reading Attitude Measurement for Enhancing Elementary School Students' Achievement. Procedia - Social and Behavioral Sciences, 116, 3213-3217. https://doi.org/10.1016/j.sbspro.2014.01.737

Dashtestani, R. (2013). Implementing mobile-assisted language learning (MALL) in an EFL context: Iranian EFL teachers' perspectives on challenges and affordances. The JALT CALL Journal, 9(2), 149-168. https://doi.org/10.29140/jaltcall.v9n2.153

Destiyanti, C., Amin, M., \& Putera, L. J. (2021). Gender-Based Analysis of Students' Ability in Answering Factual and Vocabulary-in-Context Questions of the TOEFL-Like Reading Comprehension Test. Palapa: Jurnal Studi Keislaman Dan Ilmu Pendidikan, 9(1). https://doi.org/10.36088/palapa.v9i1.926

Eugenia, Raymond, \& Leung, W. N. (2013). Ready for 21st-century Education - Pre-service Music Teachers Embracing ICT to Foster Student-centered Learning. Procedia - Social and Behavioral Sciences, 73. https://doi.org/10.1016/j.sbspro.2013.02.047

Gharti, L. (2019). Self-directed learning for learner autonomy: Teachers' and students' perceptions. Journal of NELTA Gandaki, 1, 62-73. https://doi.org/10.3126/jong.v1i0.24461

Gozcu, E., \& Caganaga, C. K. (2016). The importance of using games in EFL classrooms. Cypriot Journal of Educational Sciences, 11(3), 126. https://doi.org/10.18844/cjes.v11i3.625

Habibi, N. (2017). The Use of Flashcards in Improving Vocabulary Mastery of Students with Disability. Inklusi Journal Of Disability Studies, 121. https://doi.org/10.14421/ijds.040203

Hancock, B. (2006). An Introduction to Qualitative Research Au t hors. Qualitative Research, 4th, 504. https://doi.org/10.1109/TVCG.2007.70541

Hasiana, \& Wirastania. (2018). Pengaruh Musik dalam Mengembangkan Kemampuan Mengenal Bilangan Siswa Kelompok A di TK Lintang Surabaya. Jurnal Obsesi, 1(2), 131-138. https://doi.org/10.31004/obsesi.v1i2.25

Hua, M., \& Wang, L. (2021). Effects of socioeconomic status on children's vocabulary brain development. Aggression and Violent Behavior, 7. https://doi.org/10.1016/j.avb.2021.101670

Ifadah, M., \& Aimah, S. (2018). Keefektifan Lagu Sebagai Media Belajar Dalam Pengajaran Pronounciation/Pengucapan. Seminar Hasil-Hasil Penelitian - LPPM UNIMUS, 336-370.

Khalil, Z. M. (2018). EFL Students' Perceptions towards Using Google Docs and Google Classroom as Online Collaborative Tools in Learning Grammar. Applied Linguistics Research Journal, 2(2), 33-48. https://doi.org/10.14744/alrj.2018.47955

Kusumawati, P., Sudirman, \& Kusuma, P. I. (2017). the Effect of Digital Flashcard on Students ' Vocabulary Mastery of the Fourth Grade Students At Sd Negeri 1 \& 2 Paket Agung in the Academic Year 2016 / 2017. Jurnal Pendidikan Bahasa Inggris Undiksha, 5(2). https://doi.org/10.23887/jpbi.v5i2.13324

Lawson-Adams, J., Dickinson, D. K., \& Donner, J. K. (2022). Sing it or speak it?: the effects of sung and rhythmically spoken songs on preschool children's word learning. Early Childhood Research Quarterly, 58. https://doi.org/10.1016/j.ecresq.2021.06.008

Leona, N. L., Koert, M. J. H. van, Molen, M. W. van der, Rispens, J. E., Tijms, J., \& Snellings, P. (2021). Explaining individual differences in young English language learners' vocabulary knowledge: The role of 
Extramural English Exposure and motivation. System, 96. https://doi.org/10.1016/j.system.2020.102402

Lestari, Kristiantari, \& Ganing. (2017). Pengaruh Model Pembelajaran Talking Stick Berbantuan Lagu Daerah Terhadap Hasil Belajar IPS. International Journal Of Elementary Education, 4(1). https://doi.org/10.23887/ijee.v1i4.12960.

Lou, S.-J., Lin, T.-C., Hsin, T.-H., Shih, R.-C., \& Cheng, T.-F. (2013). Effects of Applying Blended Teaching Approach to English Sentence Translation for Vocational High School Students. Procedia - Social and Behavioral Sciences, 106. https://doi.org/10.1016/j.sbspro.2013.12.113

Nisa, A., Sudarmin, \& Samini. (2015). Efektivitas Penggunaan Modul Terintegrasi Etnosains Dalam Pembelajaran Berbasis Masalah Untuk Meningkatkan Literasi Sains Siswa. USEJ - Unnes Science Education Journal, 4(3), 1049-1056. https://doi.org/10.15294/usej.v4i3.8860

Nur Utami, K., \& Mustadi, A. (2017). Pengembangan Perangkat Pembelajaran Tematik Dalam Peningkatan Karakter, Motivasi, Dan Prestasi Belajar Siswa Sekolah Dasar. Jurnal Pendidikan Karakter, 7(1), 14-25. https://doi.org/10.21831/jpk.v7i1.15492

Parvareshbar, F., \& Ghoorchaei, B. (2016). The Effect of Using Short Stories on Vocabulary Learning of Iranian EFL Learners. Theory and Practice in Language Studies, 6(7), 1476. https://doi.org/10.17507/tpls.0607.20

Prahesti, wantyka I., Taulany, H., \& Dewi, N. K. (2020). Gerak dan Lagu Neurokinestetik (GELATIK) untuk Menumbuhkan Kreativitas Seni Anak Usia Dini. Jurnal Obsesi : Jurnal Pendidikan Anak Usia Dini, 4(1). https://doi.org/10.31004/obsesi.v4i1.289

Prananda, G., Saputra, R., \& Ricky, Z. (2020). Meningkatkan Hasil Belajar Menggunakan Media Lagu Anak Dalam Pembelajaran IPA Sekolah Dasar. JURNAL IKA, 8(2), 304-314. https://doi.org/10.36841/pgsdunars.v8i2.830

Rani, Ardana, \& Negara. (2019). Pengaruh Model Pembelajaran Talking Stick Berbantuan Lagu Tradisional Terhadap Kompetensi Pengetahuan IPA. Jurnal Mimbar Ilmu, 24(3). https://doi.org/10.23887/mi.v24i3.21676

Ratminingsih, N. M. (2018). Implementasi Board Games Dan Pengaruhnya Terhadap Hasil Belajar Bahasa Inggris. Jurnal Ilmu Pendidikan, 24(1), 19. https://doi.org/10.17977/um048v24i1p19-28

Risnawati, A., \& Nuraeni, L. (2019). Meningkatkan Kemampuan Berbahasa Sunda Anak Usia Dini Melalui Kegiatan Rebo Nyunda Di Pendidikan Anak Usia Dini. CERIA (Cerdas Energik Responsif Inovatif Adaptif), 2(5). https://doi.org/10.22460/ceria.v2i5.p243-250

Roffiq, A., Qiram, I., \& Rubiono, G. (2017). Media Musik dan Lagu pada Proses Pembelajaran. JPDI (Jurnal Pendidikan Dasar Indonesia), 2(2), 35. https://doi.org/10.26737/jpdi.v2i2.330

Suwana, I. G. G., Artini, L. P., \& Piscayanti, K. S. (2013). The use of R.A.P. paraphrasing strategy to improve students' reading comprehension at class X.A3 in SMKN 2 Singaraja in academic year 2013/2014. Pendidikan Bahasa Inggris Undiksha, 1(1). https://doi.org/10.23887/jpbi.v1i1.3859

Talebi, M., \& Marzban, A. (2015). The Effect of Teaching Critical Reading Strategies on Advanced Iranian EFL Learners' Vocabulary Retention. Theory and Practice in Language Studies, 5. https://doi.org/10.17507/tpls.0503.17.

Utomo, A. C., Abidin, Z., \& Rigiyanti, H. A. (2020). Keefektifan Pembelajaran Project Based Learning Terhadap Sikap Ilmiah Pada Mahasiswa PGSD. Educational Journal of Bhayangkara. https://doi.org/10.31599/edukarya.v1i1.103

Zarei, A. A., \& Afshar, N. S. (2014). Multiple Intelligences As Predictors Of Reading Comprehension And Vocabulary Knowledge. Indonesian Journal Of Applied Linguistics, 4(1). https://doi.org/10.17509/ijal.v4i1.598 